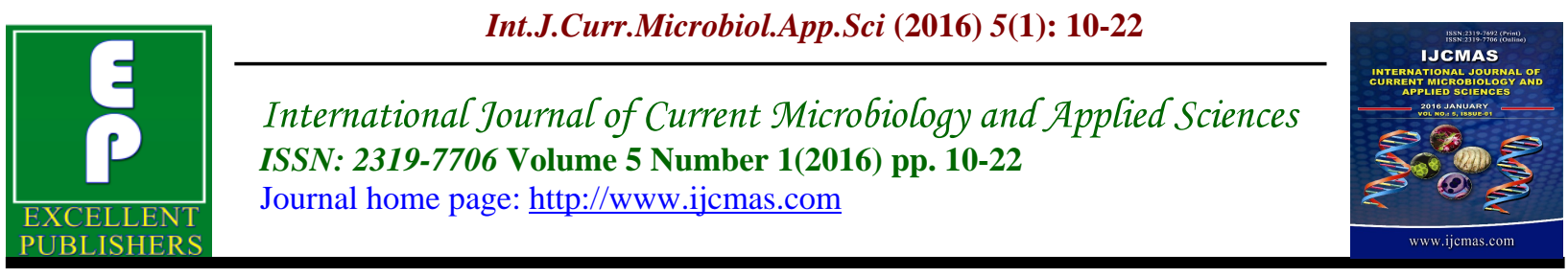

Original Research Article

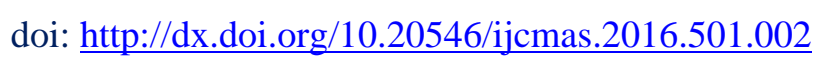

\title{
Production of Bioplastic from some selected Bacterial strains
}

\author{
Jehan Mohamed El-Mohamedy Hawas ${ }^{1 *}$, Tarek El-Said El-Banna ${ }^{1}$, \\ Elsayed Belal Abdelmonteleb Belal ${ }^{2}$ and Ahmed AhmedAbd El-Aziz ${ }^{3}$ \\ ${ }^{1}$ Professor and Chairman of Pharmaceutical Microbiology, Faculty of Pharmacy, \\ Tanta University, Egypt \\ ${ }^{2}$ Professor of Agriculture Microbiology, Faculty of Agriculture, KafrEl-Sheikh University, Egypt \\ ${ }^{3}$ Professor of Pharmaceutical Microbiology, Faculty of Pharmacy, Tanta University, Egypt \\ *Corresponding author
}

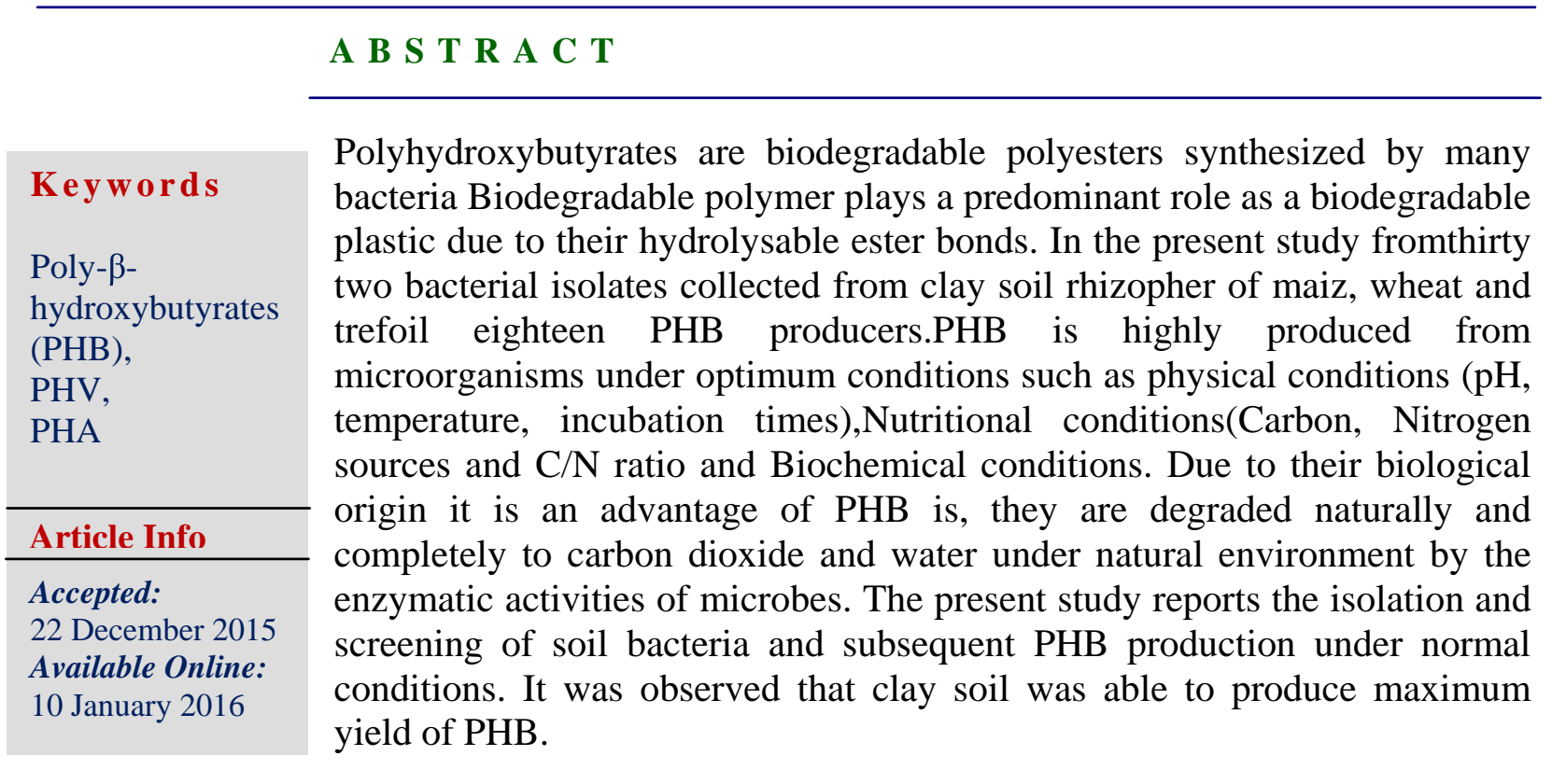

\section{Introduction}

Synthetic polymers-designated as plasticsare applied in a wide range of packaging film,containers, household, agricultural, marine and medical applicationas surgical pins and sutures and bonen replacements. Example for biodegradable polymer materials are Polyhydroxyalkanoates (PHAs) (Page, 1992b; Zhang et al., 2003). The main member of the PHA family is Polyhydroxybutyrate (PHB). PHB is accumulated inside in numerous bacteria under nutrient-limiting conditions with excess carbon. Many references show that number of microorganisms like Alcaligenes eutrophus, Azotobacter beijierinckia, Pseudomonas Oleovorans, Rhizobium sp. etc., produce PHAs as reserve food material. PHB degrade naturally and completely to $\mathrm{CO} 2$ and $\mathrm{H} 2 \mathrm{O}$ under natural environment by different microorganisms (Holmes, 1985; Bonartseva et al., 1994; Dahi et al., 1995; Lee, 1996; Yu et al., 2000; Morita et al., 
2001; Mahishi et al., 2003; Das et al., 2005; Philip et al., 2007and panigrahi et al.,2013).

The study focused on the producing of poly$\beta$-hydroxybutyrate (PHB) granules by strains isolated from different soil samples. There were Screening, isolation, and optimization techniques done for the bacteria by using various techniques. The poly- $\beta$-hydroxybutyrate (PHB) granules production was tested by using various sources of $\mathrm{C} \& \mathrm{~N}, \mathrm{C}: \mathrm{N}$ ratios, concentrations of $\mathrm{C} \& \mathrm{~N}$ used, and the effect of $\mathrm{pH}$, incubation times, different fermentation media and different temperature.

It was noticed that maximum density of PHB granules was recorded from the clay soil strains.

\section{Materials and Methods}

All chemicals were purchased from s d fine chemicals and were of analytical grade.

Medium: Sucrose/Yeast extracts (Bormann et al., 1998).

\section{Sample Collection and Isolation of Pure Cultures}

Clay soil sample was collected in clean bags. One gram of soil sample is dispensed in $10 \mathrm{ml}$ of sterile distilled water. This is mixed vigorously and $1 \mathrm{ml}$ from this is taken and added to another tube with $9 \mathrm{ml}$ sterile distilled water to get a dilution of $10^{-1}$. This serial dilution is repeated to get dilutions of $10^{-2}, 10^{-3}, 10^{-4}, 10^{-5}, 10^{-6}$ and $10^{-7}$.

For the isolation of organisms, $0.1 \mathrm{ml}$ of each dilution was plated onto a nutrient rich medium by spread plate method for the propagation of microbial growth. The plates were incubated at $30^{\circ} \mathrm{c}$ for 48 hours. Colonies with different characteristic features were maintained as pure cultures on nutrient agar slants and stored at $4{ }^{\circ} \mathrm{C}$.

\section{Screening of PHB Producing Bacteria}

All the bacterial isolates were qualitatively tested for PHB production following the viable colony method of screening using Nile red Dye (Rhem and Valla 1997 and Spiekermann et al.,1999). For this screening of PHB producers, $20 \mu \mathrm{l}$ was spread onto sterilized pre-made (sucrose/yeast extract agar media) plates to reach a final concentrations of $0.5 \mu \mathrm{g}$ Nile red $/ \mathrm{ml}$ medium. After inoculation, the plates were incubated overnight at $30{ }^{\circ} \mathrm{C}$ subsequently.

The prepared clay soil samples were subcultured by $0.1 \mathrm{ml}$ samples were spread out with a sterilized glass rod over the surface of sucrose/yeast extract agar media. The plates were incubated at $30{ }^{\circ} \mathrm{C}$ for $48 \mathrm{hrs}$. Colonies with pinkish pigment indicated PHB production isolates were exposed to ultraviolet light $(312 \mathrm{~nm})$ to detect the accumulation of PHB according to The lighted plates were recorded positives, after that these isolates were picked up and purified by sub-cultured on the same media.

\section{Cell Dry Weight}

After $48 \mathrm{hrs}$ incubation at $37^{\circ} \mathrm{C}$, culture medium was collected and centrifuged at $10,000 \mathrm{rpm}$ for $15 \mathrm{~min}$. Supernatant was discarded and the cell pellet was washed twice in deionized water, recovered (for 4 min at $10000 \mathrm{rpm}$ at $4^{\circ} \mathrm{C}$ ). The cell pellet was dried $24 \mathrm{hr}$ at $100^{\circ} \mathrm{C}$ then the total bacterial cell dry weight was determined as $\mathrm{g} / \mathrm{L}$ : (Kuniko et al., 1988, Boweker et al., 1981, Ishizaki et al., 1991 and Du et al.,2001 ).

\section{Extraction and Quantification of PHB}

All the Nile red positives isolates were 
subjected to quantification of PHB production as per the method of Williamson and Wilkinson, 1958 and Arnold et al., 1999). The bacterial cells containing the polymer were centrifuged at 10,000 rpm for $10 \mathrm{~min}$ and the pellet was re suspended into alkaline sodium hypochlorite $(\mathrm{pH}$ 10.0-10.5 $\mathrm{NaOCl}$ content $5.25 \%-5.5 \%$ ) and incubated at room temperature for $1 \mathrm{hr}$. The whole mixture was again centrifuged at10,000 rpm for 10min.and the supernatant was discarded. The cell pellet containing PHB was again washed with water, alcohol and acetone. Finally, the polymer was dried for 2 hr. at $105^{\circ} \mathrm{C}$ and then weighed. Dry weight of extracted PHB was estimated as $\mathrm{g} / \mathrm{L}$. Residual biomass was estimated as the difference between dry cell weight and dry weight of PHB (Zakaria et al., 2010).

\section{Estimation of PHB from the Tested Isolates}

The percentage of intracellular PHB accumulation is estimated as the percentage composition of PHB present in the dry cell weight.

PHB accumulation $(\%)=$ Dry weight of extracted PHB $(\mathrm{g} / \mathrm{L}) \times 100 / \mathrm{DCW}(\mathrm{g} / \mathrm{L})$

\section{Identification of PHB Producing Isolates}

PHB producing strains were identified and characterized by morphological and biochemical characterization according to the Bergey's Manual of Systematic Bacteriology.

\section{Morphological Characterization}

Morphological features were identified by growing the cultures on nutrient agar media and gram staining was performed.

\section{Biochemical Characterization}

Different Biochemical tests were carried out includes, Catalase test, Oxidase test, Pigment production and $16 \mathrm{~S} \quad \mathrm{r}$ DNA Cataloging.

\section{Optimization of Cultural Parameters for Maximum PHB Production}

Different factors affecting PHB production by the selected bacterial isolates were optimized.

\section{Effect of Different Temperatures}

The medium sucrose /yeast extract broth medium were prepared and adjust $\mathrm{pH}$ at 7.0. The bacterial isolate $\mathrm{J} 1$ were grown in conical flask $(250 \mathrm{ml})$ containing $100 \mathrm{ml}$ of medium were sterilized at $121^{\circ} \mathrm{C}$ for $20 \mathrm{~min}$. The cultures were incubated on a rotary shaker at 20,30 and $40^{\circ} \mathrm{C}$ and $150 \mathrm{rpm}$ for $48 \mathrm{hr}$. and PHB was quantified.

\section{Effect of Different pH}

The bacterial isolate $\mathrm{J} 1$ were grown in conical flask $(250 \mathrm{ml})$ containing $100 \mathrm{ml}$ media and were sterilized at $121^{\circ} \mathrm{C}$ for 20 min.. The medium sucrose /yeast extract broth medium were prepared with different $\mathrm{pH}$ ranging from $(6,7,8$ and 9$)$ and the inoculated flasks were incubated at $30^{\circ} \mathrm{C}$ at $150 \mathrm{rpm}$ for $48 \mathrm{hr}$. and PHB was quantified.

\section{Effect of Different Incubation Times}

The bacterial isolate $\mathrm{J} 1$ was grown in conical flask $(250 \mathrm{ml})$ with $100 \mathrm{ml}$ sucrose /yeast extract broth medium and adjust $\mathrm{pH}$ at 7.0 were sterilized at $121^{\circ} \mathrm{C}$ for $20 \mathrm{~min}$ The inoculated flasks were incubated at $30^{\circ} \mathrm{C}$ at $150 \mathrm{rpm}$ under different incubation times (24, 48, 72, 96 hr.).After 48 hr., PHB produced were quantified.

\section{Effect of Different Media}

The different media sucrose/yeast extract 
medium M1 Bormann et al., (1998), M2 Burdman et al., (1998), M3 (Banziger and Tobler, 2001), and synthetic medium M4 Wang et al., (2007) were used. The bacterial isolate J1were grown in conical flask (250 $\mathrm{ml}$ ) containing $100 \mathrm{ml}$ of each previous media and were sterilized at $121^{\circ} \mathrm{C}$ for 20 $\mathrm{min}$. The inoculated flasks were incubated at $30^{\circ} \mathrm{C}$ at $150 \mathrm{rpm}$ for $48 \mathrm{hr}$. and PHB was quantified.

\section{Effect of Different Carbon and Nitrogen Sources}

The selected bacterial isolate $\mathrm{J} 1$ were grown in $250 \mathrm{ml}$ conical flasks containing $100 \mathrm{ml}$ Sucrose yeast extract broth medium with different carbon sources like glucose, sucrose, mannitol, lactose, whey and molasses with different concentrations (1\%, $2 \%, 3 \% \mathrm{w} / \mathrm{v})$. The flasks were incubated at $30^{\circ} \mathrm{C}$ on a rotary shaker $(150 \mathrm{rpm})$ for 48 hours. After incubation, PHB produced by the isolates were quantified according to Miller (1959), Santimano et al. (2009), Ghate et al. (2011).

\section{Effect of Different Nitrogen Sources on PHB Production}

The bacterial isolate $\mathrm{J} 1$ were grown in 250 $\mathrm{ml}$ conical flasks containing $100 \mathrm{ml}$ sucrose yeast extract broth medium with the best carbon source, and different ' $\mathrm{N}$ ' sources were used like ammonium sulfate, ammonium chloride, and yeast extract, all at different concentrations (0.5, 1, $1.5 \mathrm{~g} / \mathrm{L})$. After 48 hr., PHB yields were quantified.

\section{Effect of Different C:N Ratios on PHB Production}

The bacterial isolate $\mathrm{J} 1$ were grown in 250 $\mathrm{ml}$ conical flasks containing $100 \mathrm{ml}$ sucrose yeast extract broth medium with different $\mathrm{C}: \mathrm{N}$ ratios i.e. 15:1, 20;1 and 25:1 using the best $\mathrm{C}$ and $\mathrm{N}$ sources and incubated on a rotary shaker $(150 \mathrm{rpm})$ at 300C. After 48 hr., PHB yields were quantified according to Khanna et al., 2005, Belal 2013 and Panigrahi et al., 2013).

\section{Results and Discussion}

\section{Isolation of microorganisms}

Microorganisms were isolated from clay soil sample was obtained by serial dilution. A total of 32 bacterial colonies were selected and the numbers were given to each colony. These colonies were streaked on enrichment and nutrient agar medium plates and preserved for further studies.

\section{Screening of PHB Producing Bacteria}

Among 32 colonies, 18 colonies showed positive pinkish colony for Nile red staining. Table (2) and Figure (1) showed the values of PHB according to dry cell weight and referred that the intensity of fluorescence according to PHB amount. The percentage of PHB from $1.50-30.40 \%$ and the highest productivity PHB $(30.40 \%)$ was obtained by bacterial isolate designated as $\mathrm{J} 1$.

\section{Extraction and Quantification of PHB}

The best method of PHB extraction was by sodium hypochlorite and it was selected in the further experiments. The percentage of intracellular PHB accumulation was estimated as the percentage composition of PHB present in the dry cell weight. Residual biomass was estimated as difference between the dry cell weight and dry extract of PHB.

\section{Identification of PHB Producing Isolates}

\section{Morphological and Biochemical Characteristics}

The $\mathrm{J} 1$ isolate was gram negative, non-spore 
forming, the cell was short rods. And the biochemical studies indicated that these strains should be classified into Pseudomonas sp. J1as shown in table (3).

\section{The16S r DNA Cataloging}

The 16S r DNA sequence can be clearly seen that the isolated bacterial strain 1 shown in Figures (2) and closely related to the species Pseudomonas boreopolis. It showed that the highest sequence similarities with 97\% for Pseudomonas boreopolis.

Table.1

\begin{tabular}{|l|l|l|l|}
\hline $\begin{array}{l}\text { source of } \\
\text { microorganisms }\end{array}$ & $\begin{array}{l}\text { No. of } \\
\text { collected } \\
\text { samples }\end{array}$ & $\begin{array}{l}\text { Producer } \\
\text { PHB }\end{array}$ & Non producer PHB \\
\hline Clay soil & & & \\
Rhizosphere of: & 13 & 9 & 4 \\
maize & 11 & 4 & 7 \\
wheat & 8 & 5 & 3 \\
trefoil & 32 & 18 & 14 \\
\hline Total & \multicolumn{2}{|l}{} \\
\hline
\end{tabular}

Table.2

\begin{tabular}{|c|c|c|c|}
\hline $\begin{array}{c}\text { Code No. of } \\
\text { isolate }\end{array}$ & $\mathbf{D C W}(\mathbf{g} / \mathbf{L})$ & PHB $(\mathbf{g} / \mathbf{L})$ & $\begin{array}{c}\text { Yield of PHB } \\
\text { \% }\end{array}$ \\
\hline J1 & $5.46 \pm 0.23$ & $1.55 \pm 0.11$ & $30.40 \%$ \\
\hline J3 & $5.51 \pm 0.244$ & $0.41 \pm 0.101488916$ & $7.80 \%$ \\
\hline J4 & $5.43 \pm 0.089$ & $0.5 \pm 0.02$ & $9.20 \%$ \\
\hline J5 & $6 \pm 0.32$ & $0.09 \pm 0.01$ & $1.50 \%$ \\
\hline J6 & $5.62 \pm 0.35$ & $0.4 \pm 0.09$ & $6.92 \%$ \\
\hline J7 & $5.32 \pm 0.171$ & $0.33 \pm 0.02$ & $6.20 \%$ \\
\hline J8 & $5.62 \pm 0.244$ & $0.45 \pm 0.11$ & $8.00 \%$ \\
\hline J9 & $5.26 \pm 0.212$ & $0.4 \pm 0.05$ & $7.60 \%$ \\
\hline J10 & $5.37 \pm 0.106$ & $0.70 \pm 0.10$ & $13.40 \%$ \\
\hline J11 & $5.506 \pm 0.22$ & $0.66 \pm 0.09$ & $12.00 \%$ \\
\hline J12 & $5.34 \pm 0.130$ & $0.48 \pm 0.18$ & $7.30 \%$ \\
\hline J13 & $5.47 \pm 0.097$ & $0.63 \pm 0.1$ & $11.50 \%$ \\
\hline J14 & $5.46 \pm 0.269$ & $0.53 \pm 0.11$ & $9.70 \%$ \\
\hline J15 & $5.43 \pm 0.148$ & $0.63 \pm 0.12$ & $11.40 \%$ \\
\hline J16 & $5.52 \pm 0.119$ & $0.72 \pm 0.12$ & $12.70 \%$ \\
\hline J17 & $5.536 \pm 0.069$ & $0.77 \pm 0.08$ & $12.20 \%$ \\
\hline J18 & $5.83 \pm 0.0898$ & $0.7 \pm 0.21$ & $12.00 \%$ \\
\hline J19 & $5.38 \pm 0.187$ & $0.21 \pm 0.09$ & $3.90 \%$ \\
\hline
\end{tabular}

DCW: Dry cell weight

PHB: polyhydroxybutyrate 
Table.3 Morphological and Physiological Characteristics of the Efficient PHB Production Isolates (J1)

\begin{tabular}{|l|l|}
\hline Test & Result \\
\hline Shape of cell & Short rods \\
\hline Sporulation & Non-spore former \\
\hline Motility & Motile \\
\hline Gram reaction & Gram-ve \\
\hline Aerobic growth & Facultative \\
\hline Anaerobic growth & - \\
\hline Pigment production & + \\
\hline Oxidase test & + \\
\hline
\end{tabular}

+Growth- No growth

Table.4 Effect of Different Temperature on PHB Production by P. Boreopolis $\mathrm{J} 1$

\begin{tabular}{|c|c|c|c|}
\hline \multirow{2}{*}{ Temperatures } & \multicolumn{3}{|c|}{ P. boreopolis J1 } \\
\cline { 2 - 4 } & DCW (g/L) & PHB (g/L) & $\begin{array}{c}\text { Yield of PHB } \\
(\%)\end{array}$ \\
\hline $\mathbf{2 0}^{\circ} \mathbf{C}$ & $2.76 \pm 0.2$ & $1.2 \pm 0.11$ & $43 \%$ \\
\hline $\mathbf{3 0}^{\circ} \mathbf{C}$ & $5 \pm 0.2$ & $3.5 \pm 0.13$ & $70 \%$ \\
\hline $\mathbf{4 0}^{\circ} \mathbf{C}$ & $0 \pm 0$ & $0 \pm 0$ & $0 \%$ \\
\hline
\end{tabular}

DCW: Dry cell weight

PHB: polyhydroxybutyrate

Table.5 Effect of Different $\mathrm{pH}$ on Production of PHB by P. Boreopolis J1

\begin{tabular}{|c|c|c|c|}
\hline \multirow{2}{*}{$\mathbf{p H}$} & \multicolumn{3}{|c|}{ P. borepolisJ1 } \\
\cline { 2 - 4 } & DCW $(\mathbf{g} / \mathbf{L})$ & PHB $(\mathbf{g} / \mathbf{L})$ & Yield PHB(\%) \\
\hline pH6 & $1.9 \pm 0.11$ & $0.8 \pm 0.1$ & $42 \%$ \\
\hline pH7 & $5.4 \pm 0.13$ & $3.3 \pm 0.12$ & $61 \%$ \\
\hline pH8 & $1.3 \pm 0.1$ & $0.5 \pm 0.14$ & $38 \%$ \\
\hline pH9 & $1 \pm 0.2$ & $0.3 \pm 0.1$ & $20 \%$ \\
\hline
\end{tabular}

DCW: Dry cell weight

PHB: polyhydroxybutyrate

Table.6 Effect of Different Incubation Times on PHB Production by P. BorepolisJ1

\begin{tabular}{|c|c|c|c|}
\hline Incubation times & \multicolumn{3}{|c|}{ P. boreopolis J1 } \\
\hline & DCW $(\mathbf{g} / \mathbf{L})$ & PHB (g/L) & Yield PHB(\%) \\
\hline $24 \mathrm{hr}$ & $4.76 \pm 0.3$ & $2.1 \pm 0.2$ & $44 \%$ \\
\hline $48 \mathrm{hr}$ & $3.9 \pm 0.3$ & $2.9 \pm .0 .16$ & $74 \%$ \\
\hline $72 \mathrm{hr}$ & $4.766 \pm 0.198$ & $1.9 \pm 0.2$ & $39.50 \%$ \\
\hline $96 \mathrm{hr}$ & $3.4 \pm 0.21$ & $1 \pm 0.2$ & $29 \%$ \\
\hline
\end{tabular}

DCW: Dry cell weight

PHB: polyhydroxybutyrate 
Table.7 Effect of Different Fermentation Media on PHB Production by P. boreopolisJ1

\begin{tabular}{|c|c|c|c|}
\hline Media & \multicolumn{3}{|c|}{ P. boreopolis J1 } \\
\hline & DCW $(\mathbf{g} / \mathbf{I})$ & PHB $(\mathbf{g} / \mathbf{I})$ & Yield PHB(\%) \\
\hline M1 & $4.6 \pm 0.1$ & $2.8 \pm 0.11$ & $61 \%$ \\
\hline M2 & $1.2 \pm 0.1$ & $0.5 \pm 0.2$ & $42 \%$ \\
\hline M3 & $3 \pm 0.11$ & $0.5 \pm 0.03$ & $16 \%$ \\
\hline M4 & $3.11 \pm 0.12$ & $1.25 \pm 0.1$ & $40 \%$ \\
\hline
\end{tabular}

DCW: Dry cell weight

PHB:polyhydroxybutyrate

Table.8 Effect of Different Concentration of Carbon Sources on PHB Production (P. boreopolis $\mathrm{J} 1)$

\begin{tabular}{|c|c|c|c|c|c|c|c|c|c|}
\hline \multirow[b]{2}{*}{$\begin{array}{l}\text { Carbon } \\
\text { sources }\end{array}$} & \multicolumn{3}{|c|}{$1 \%$} & \multicolumn{3}{|c|}{$2 \%$} & \multicolumn{3}{|c|}{$3 \%$} \\
\hline & $\begin{array}{r}\text { DCW } \\
(\mathrm{g} / \mathrm{L})\end{array}$ & $\begin{array}{l}\text { PHB } \\
(\mathrm{g} / \mathrm{L})\end{array}$ & \begin{tabular}{|c|}
$\begin{array}{c}\text { Yield of } \\
\text { PHB } \\
(\%)\end{array}$ \\
\end{tabular} & $\begin{array}{c}\text { DCW } \\
(\mathrm{g} / \mathrm{L})\end{array}$ & $\begin{array}{l}\text { PHB } \\
(\mathrm{g} / \mathrm{L})\end{array}$ & \begin{tabular}{|c}
$\begin{array}{c}\text { Yield of } \\
\text { PHB } \\
(\%)\end{array}$ \\
\end{tabular} & $\begin{array}{c}\text { DCW } \\
(\mathrm{g} / \mathrm{L})\end{array}$ & $\operatorname{PHB}(\mathrm{g} / \mathrm{L})$ & \begin{tabular}{|c}
$\begin{array}{c}\text { Yield of } \\
\text { PHB } \\
(\%)\end{array}$ \\
\end{tabular} \\
\hline Sucrose & $2.85 \pm 0.35$ & $1.3 \pm 0.4$ & $42 \%$ & $3.7 \pm 0.3$ & $3.1 \pm 0.3$ & $83.7 \%$ & $\begin{array}{c}2.013 \pm 0.3 \\
15\end{array}$ & $0.9 \pm 0.2$ & $42.8 \%$ \\
\hline Glucose & $3.01 \pm 0.11$ & $\begin{array}{c}1.93 \pm 0.07 \\
5\end{array}$ & $64 \%$ & $\begin{array}{c}2.37 \pm 0.08 \\
5\end{array}$ & $\begin{array}{l}1.47 \pm \\
0.095\end{array}$ & $62 \%$ & $\begin{array}{c}2.666 \pm 0.1 \\
10\end{array}$ & $\begin{array}{c}1.543 \pm 0.0 \\
9 \\
\end{array}$ & $57.8 \%$ \\
\hline Mannitol & $4.01 \pm 0.13$ & $\begin{array}{c}2.75 \pm 0.09 \\
5\end{array}$ & $69 \%$ & $3.72 \pm 0.3$ & $\begin{array}{c}3.036 \pm 0.0 \\
56 \\
\end{array}$ & $81 \%$ & \begin{tabular}{|c|}
$4.096 \pm 0.1$ \\
15 \\
\end{tabular} & $\begin{array}{c}3.013 \pm 0.1 \\
00\end{array}$ & $74 \%$ \\
\hline Whey & $1.91 \pm 0.18$ & $\begin{array}{c}0.93 \pm 0.07 \\
5\end{array}$ & $49 \%$ & $2.38 \pm 0.05$ & $0.93 \pm 0.35$ & $55 \%$ & $\begin{array}{c}2.83 \pm 0.15 \\
2\end{array}$ & $1.05 \pm 0.06$ & $57 \%$ \\
\hline Lactose & $2.0 \pm 0.11$ & $0.6 \pm 0.03$ & $30 \%$ & $2.32 \pm 0.13$ & $\begin{array}{c}0.060 \pm 0.9 \\
2\end{array}$ & $40 \%$ & $1.8 \pm 0.90$ & $\begin{array}{c}0.45 \pm 0.02 \\
0\end{array}$ & $25 \%$ \\
\hline Molasses & $\begin{array}{c}2.95 \pm 0.24 \\
0\end{array}$ & $1.95 \pm 1.95$ & $66 \%$ & $\begin{array}{c}3.31 \pm 0.29 \\
5\end{array}$ & $2.6 \pm 0.183$ & $78 \%$ & $\begin{array}{c}3.61 \pm 0.19 \\
5\end{array}$ & $\begin{array}{c}2.65 \pm 0.10 \\
5\end{array}$ & $73 \%$ \\
\hline
\end{tabular}

DCW: Dry cell weight PHB: polyhydroxybutyrate

Table.9 Effect of Different Nitrogen Sources on PHB Production by P. BoreopolisJ1

\begin{tabular}{|c|c|c|c|c|c|c|c|c|c|}
\hline \multirow{2}{*}{$\begin{array}{l}\text { Conc. of } \\
\text { Nitrogen } \\
\text { sources }\end{array}$} & \multicolumn{3}{|c|}{$0.5 \mathrm{~g} / \mathrm{l}$} & \multicolumn{3}{|c|}{$1.0 \mathrm{~g} / \mathrm{l}$} & \multicolumn{3}{|c|}{$1.5 \mathrm{~g} / \mathrm{l}$} \\
\hline & DCW (g/L) & PHB (g/L) & $\begin{array}{c}\text { Yield } \\
\text { PHB\% } \%\end{array}$ & DCW (g/L) & PHB $(\mathrm{g} / \mathrm{L})$ & $\begin{array}{c}\text { Yield } \\
\text { PHB }(\%)\end{array}$ & DCW $(\mathrm{g} / \mathrm{L})$ & PHB (g/L) & $\begin{array}{c}\text { Yield } \\
\text { PHB }(\%)\end{array}$ \\
\hline$\left(\mathrm{NH}_{4}\right)_{2} \mathrm{SO}_{4}$ & $3.11 \pm 0.105$ & $1.88 \pm 0.12$ & $60 \%$ & $3.92 \pm 0.12$ & $\begin{array}{c}2.83 \pm \\
0.10\end{array}$ & $72 \%$ & $1.88 \pm 0.15$ & $0.92 \pm 0.1$ & $49 \%$ \\
\hline $\mathrm{NH}_{4} \mathrm{Cl}$ & $2.99 \pm 0.12$ & $1.2 \pm 0.1$ & $40 \%$ & $3.8 \pm 0.08$ & $1.9 \pm 0.11$ & $50 \%$ & $1.9 \pm 0.1$ & $0.7 \pm 0.15$ & $37 \%$ \\
\hline $\begin{array}{c}\text { Yeast } \\
\text { extract }\end{array}$ & $2.2 \pm 0.12$ & $0.8 \pm 0.1$ & $36 \%$ & $2.6 \pm 0.2$ & $\begin{array}{l}1.06 \pm \\
0.230\end{array}$ & $46 \%$ & $1.5 \pm 0.35$ & $0.3 \pm 0.028$ & $33 \%$ \\
\hline
\end{tabular}


Table.10 Effect of Different C:N Ratios of Medium on PHB Yields By P. Boreoplois ( J1 )

\begin{tabular}{|c|c|c|c|c|c|c|c|c|c|c|}
\hline \multirow[b]{2}{*}{ Strains } & \multirow[b]{2}{*}{$\begin{array}{l}\text { carbon } \\
\text { source }\end{array}$} & \multicolumn{3}{|c|}{$15: 1$} & \multicolumn{3}{|c|}{$20: 1$} & \multicolumn{3}{|c|}{$25: 1$} \\
\hline & & $\begin{array}{c}\text { DCW }(\mathrm{g} \\
/ \mathrm{L})\end{array}$ & $\begin{array}{l}\text { PHB } \\
(\mathrm{g} / \mathrm{L})\end{array}$ & $\begin{array}{c}\text { Yield } \\
\text { PHB } \\
(\%)\end{array}$ & $\begin{array}{c}\mathrm{DCW}(\mathrm{g} \\
/ \mathrm{L})\end{array}$ & $\begin{array}{l}\text { PHB } \\
(\mathrm{g} / \mathrm{L})\end{array}$ & $\begin{array}{c}\text { Yield } \\
\text { PHB } \\
(\%)\end{array}$ & $\begin{array}{c}\text { DCW } \\
(\mathrm{g} / \mathrm{L})\end{array}$ & $\begin{array}{l}\text { PHB } \\
(\mathrm{g} / \mathrm{L})\end{array}$ & $\begin{array}{c}\text { yield } \\
\text { PHB(\%) }\end{array}$ \\
\hline $\begin{array}{c}\text { P. boreopolis } \\
J 1\end{array}$ & $\begin{array}{c}\text { Ammo- } \\
\text { nium } \\
\text { sulfate }\end{array}$ & $\begin{array}{c}4.01 \\
\pm 0.13\end{array}$ & $\begin{array}{c}2.75 \\
\pm 0.09\end{array}$ & $69 \%$ & $\begin{array}{l}3.72 \\
\pm 0.3\end{array}$ & $\begin{array}{c}3.036 \\
\pm 0.056\end{array}$ & $81 \%$ & $\begin{array}{c}4.096 \\
\pm 0.115\end{array}$ & $\begin{array}{l}3.013 \\
\pm 0.100 \\
1\end{array}$ & $74 \%$ \\
\hline
\end{tabular}

Figure.1 Correlation of PHB Producing Bacteria Isolated from Clay Soil and DCW

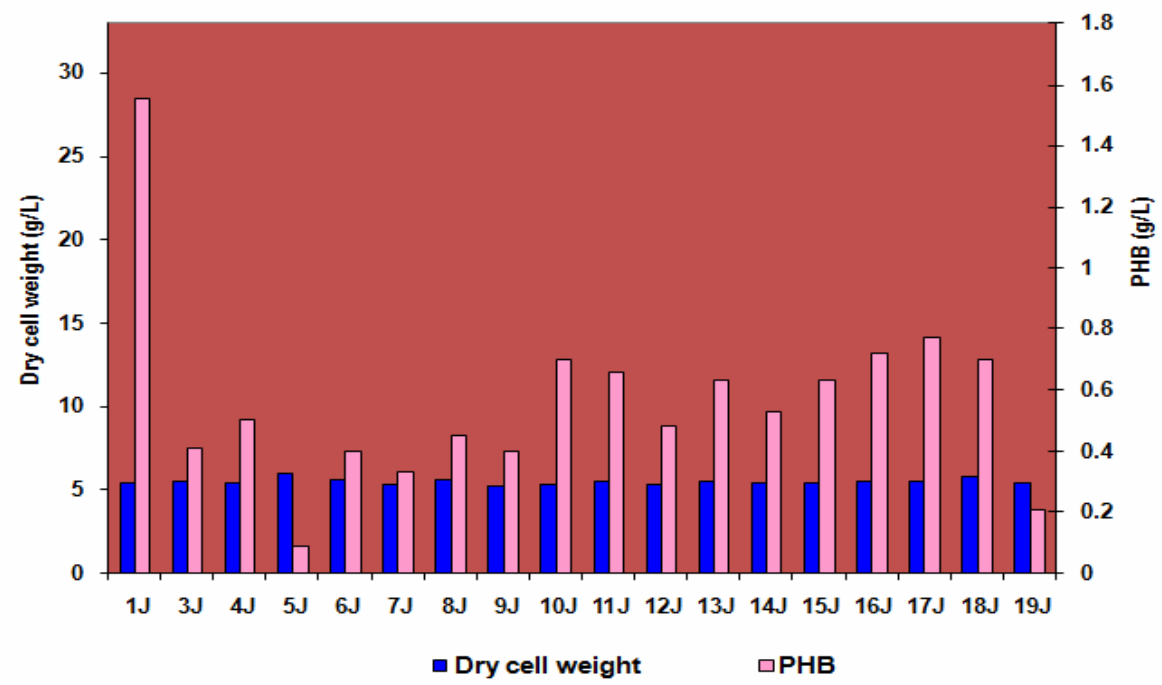

Figure.2 Dendogram illustrating the genomic relationship among fourteen isolates belonging to genus Pseudomonas revealed by UPGMA cluster analysis. The label at the internal nodes shows the distance and the bar 0.02 represents substitution

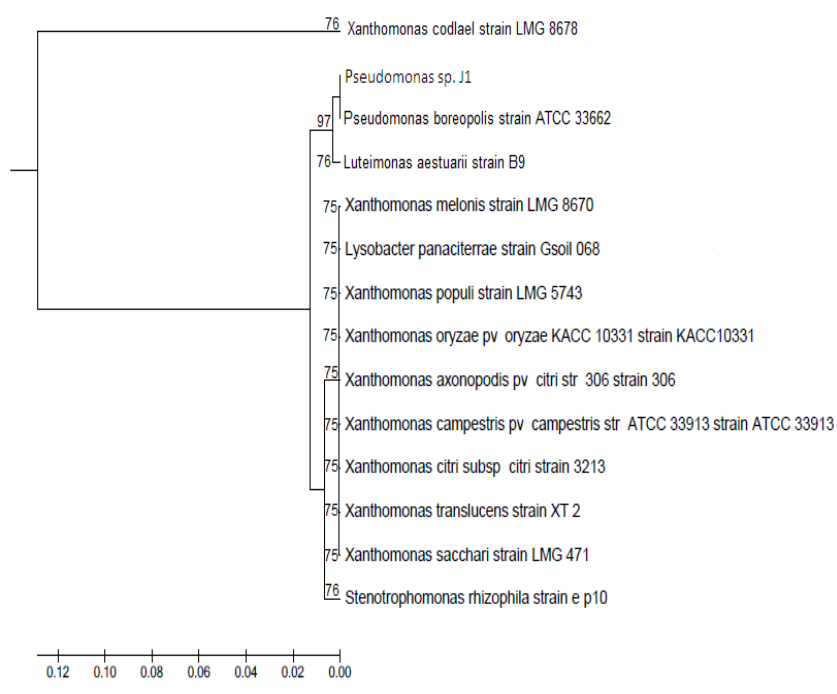


Figure.3 Effect of different temperature on PHB production by P. borepolisJ1

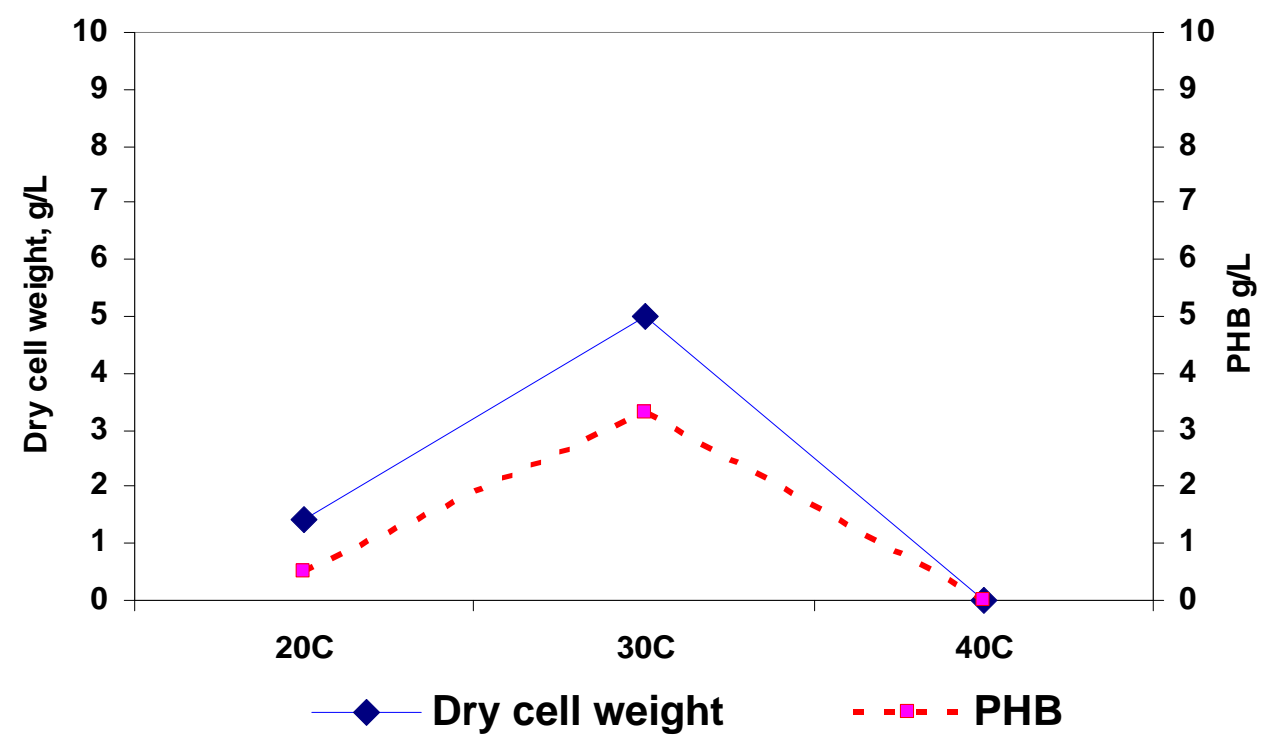

Figure.4 Effect of different $\mathrm{pH}$ on production of PHB by $P$. boreopolis J1

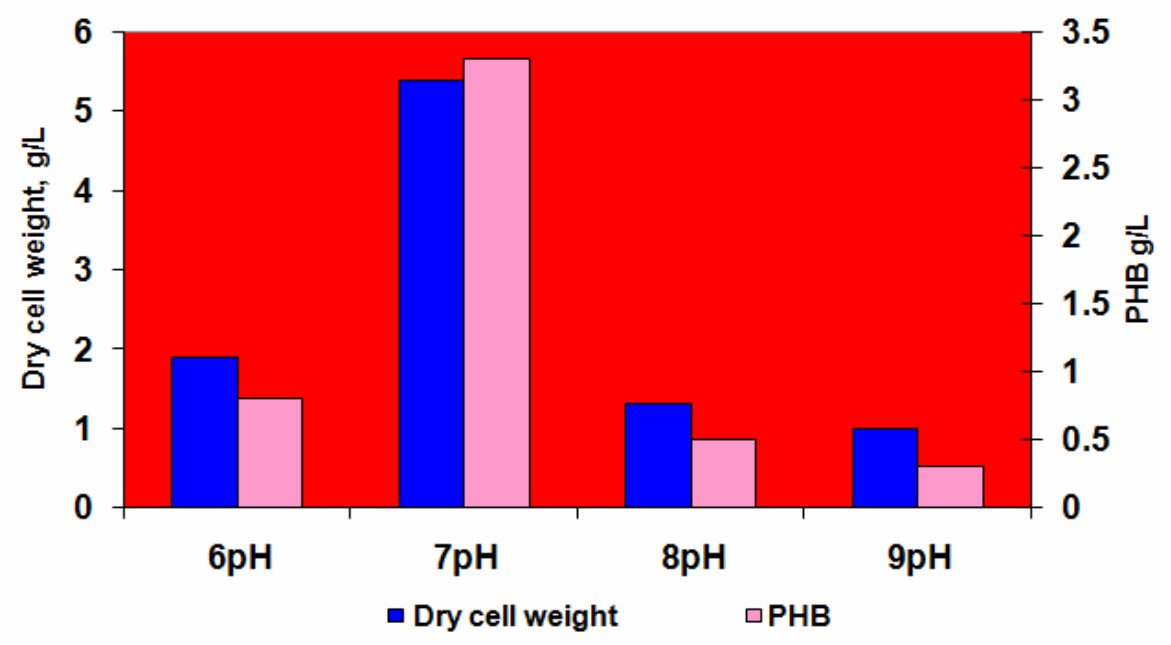

Figure.5 Effect of different Incubation times on PHB Production by P. boreopolis J1

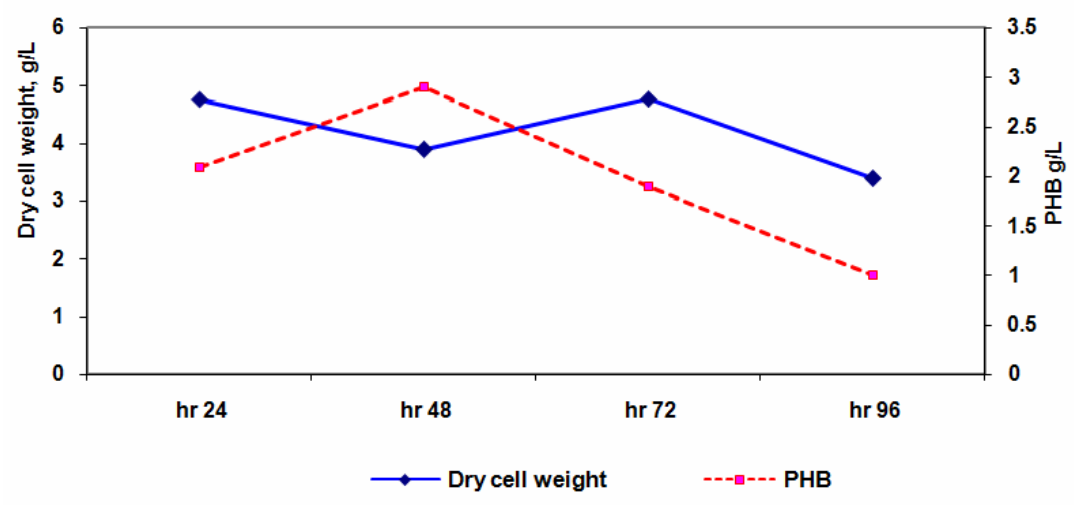


Figure.6 Effect of different Media on production of PHB by P. boreopolis $\mathrm{J} 1$

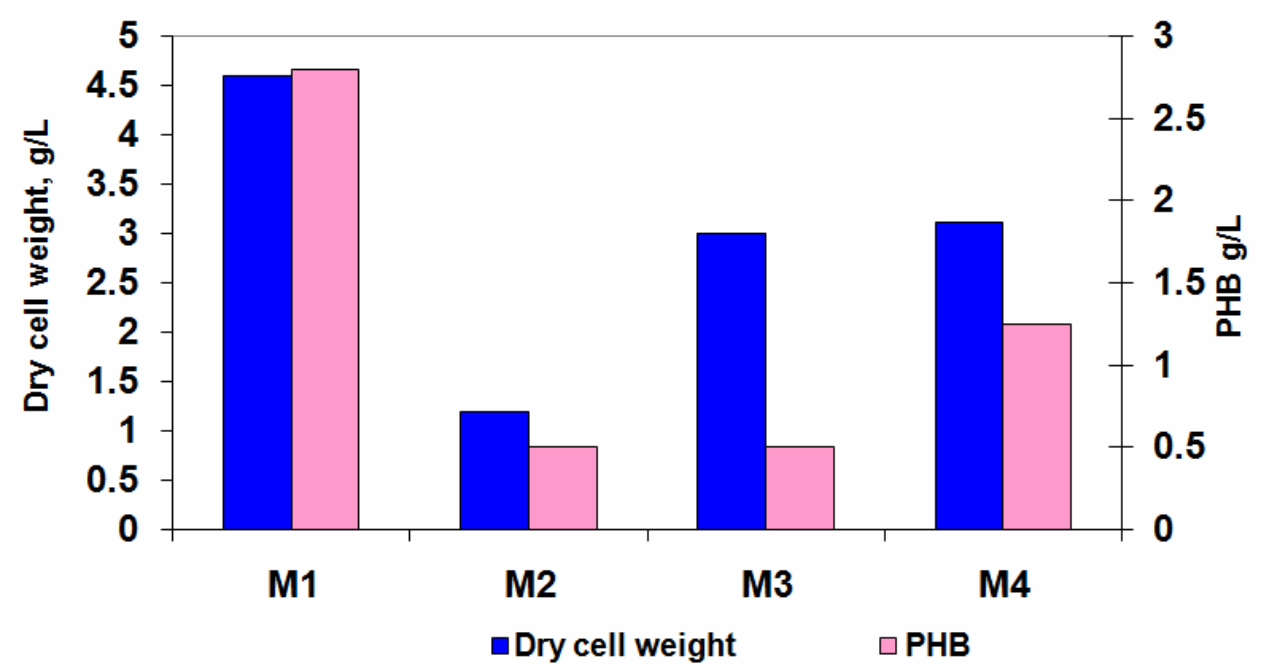

Figure.7 Effect of Different Concentration Carbon Sources on PHB Production (P. boreopolis $\mathrm{J} 1)$

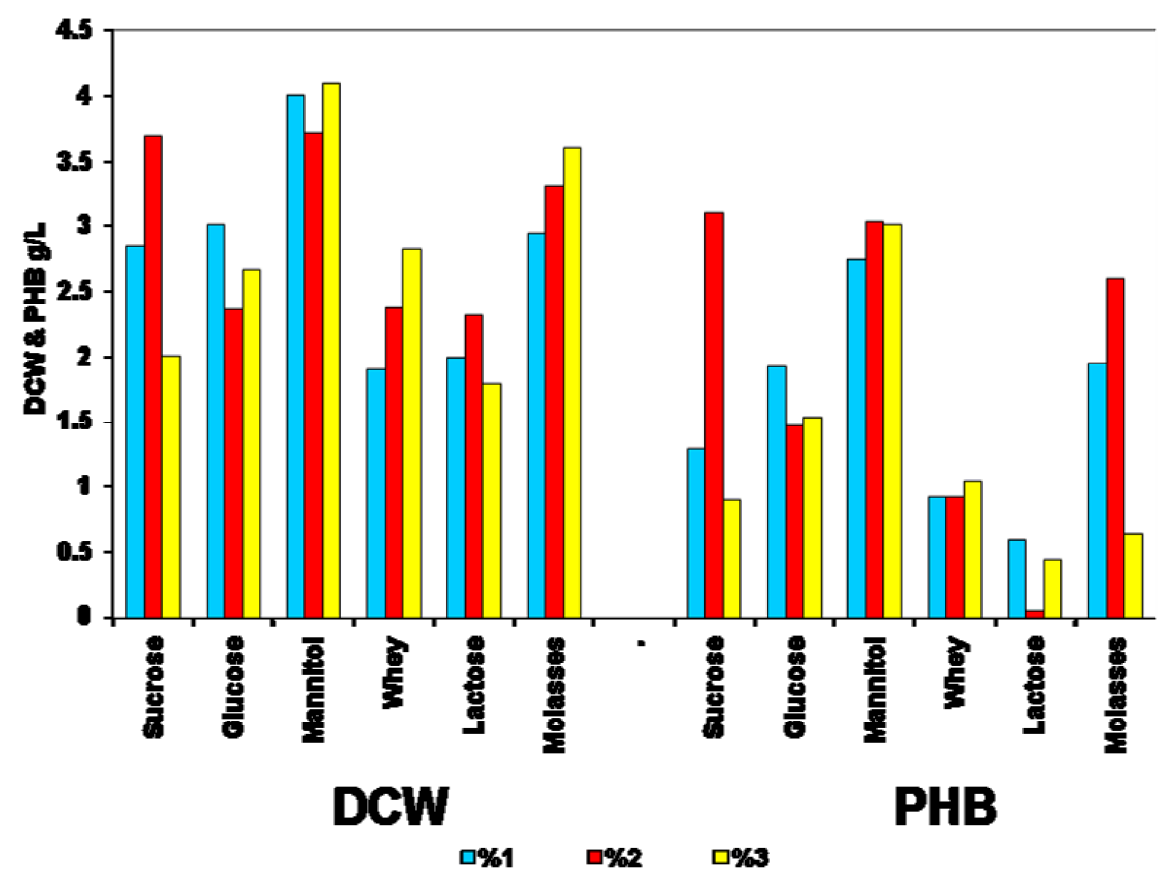


Figure.8 Effect of Different Nitrogen Sources on PHB Production (P. boreopolisJ1)

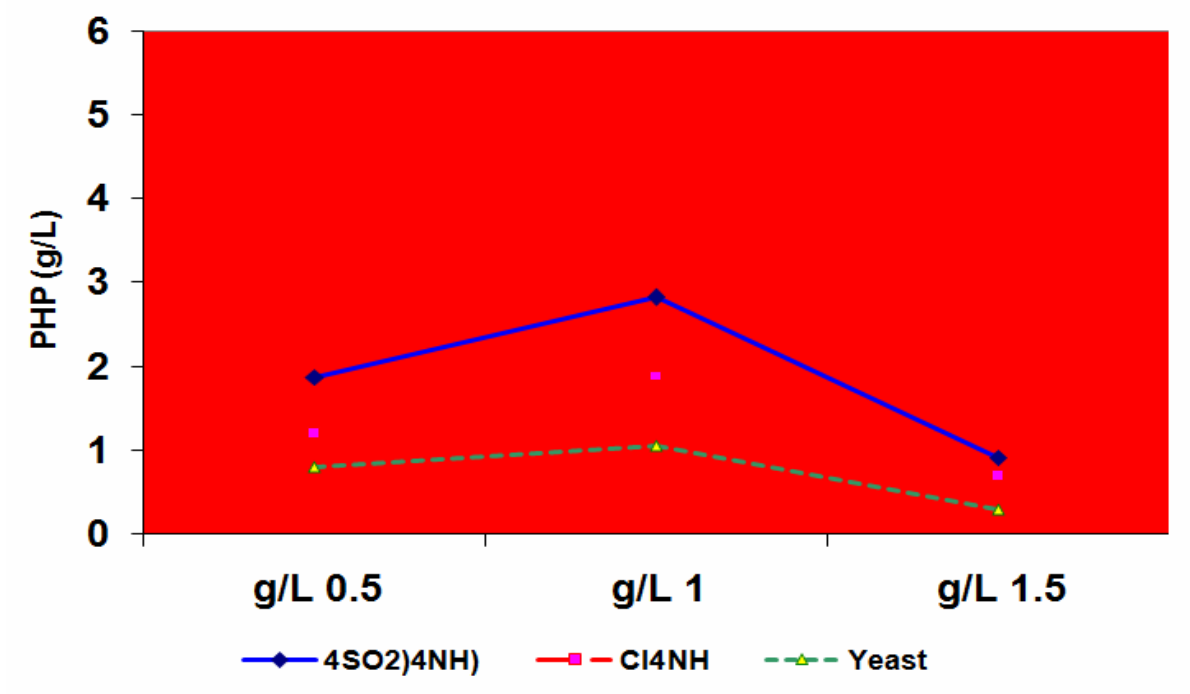

Optimization of Cultural Parameters for Maximum PHB production

Effect of Different Temperatures on Production of PHB by $P$. Boreopolis $\mathrm{J} 1$

Data presented in Table (4) and Figure (3) showed that, the maximum PHB production occurred at $30^{\circ} \mathrm{C}$ after $48 \mathrm{hr}$. of incubation at a pH 7 by $P$. boreopolis $\mathrm{J} 1$.

\section{Effect of Different $\mathrm{pH}$ on Production of PHB by $P$. Boreopolis J1}

Data presented in Table (5) and Figure(4) showed that, out of different $\mathrm{pHs}$ of media tested, $\mathrm{pH} 7.0$ was found to be optimum for maximum PHB production by P.Boreopolis.

\section{Effect of Different Incubation Time}

As shown in Table (6) and Figure (5), the highly production of PHB at incubation time $48 \mathrm{hr}$. for P.Boreopolis $\mathrm{J} 1$ isolate.

\section{Effect of Different Media}

The results presented in Table (7) and Figure (6) showed that the Sucrose yeast extract medium gave high yield of PHB by P. boreopolisJ1.
Effect of different Carbon sources on PHB production by $\mathrm{P}$. boreopolis $J 1$

Data presented in Table (8) and Figure(7) illustrate the effect of different concentrations from carbon sources on PHB yield. The highest yield of PHB among the tested carbon sources was observed with Sucrose $2 \%$ by $p$. boreopolisJ1.

\section{Effect of Different Nitrogen Sources on PHB Production}

The result presented in Table (9) and figure (8) showed that the highest yield of PHB was recorded with $1.0 \mathrm{~g} / \mathrm{L}$ ammonium sulfate by $P$. boreopolis $\mathrm{J} 1$.

\section{Effect of Different C:N Ratio on PHB Production by $\boldsymbol{P}$. Boreopolis $\mathbf{J}_{1}$}

The data are presented in Table (10) showed that, the highest yield of PHB by $P$. boreopolis J1at C:N ratio was 20:1.

In conclusion, the main aim of this present study was to isolate the PHB producing bacteria from Clay soil sample. Now Days researchers are focusing on biopolymer producing microorganisms for developing 
biodegradable plastics. The medium used for the PHB isolates was simple medium and less cost effective and the PHB yield from these isolates was high compared with the earlier reports. Among 18 isolates the strain $\mathrm{J} 1$ is showing more production of biopolymer. The PHB produced from this strain will further be characterized by analytical techniques like Infra Red spectra and Gas Chromatography analysis.

\section{References}

Arnold, L.; Demain, J. and Davis, E. (1999): Polyhydroxyalkanoates. Manual of Microbiology and Biotechnology. Washington, Am Soc. Microbiol., 2: 616627.

Banziger, S. and Tobler, N. (2001): The formation of reserve polymers in Bacillus megaterium. Microb. Ecology Course, 14.

Belal, E. B.(2013b):Production of Poly- $\beta$ Hydroxybutyric Acid (PHB) by Rhizobium elti and Pseudomonas stutzeri. Curr. Res. J. Biol. Sci., 5(6): 273 - 284.

Bergey's Manual of Systematic Bacteriology (2005), $2^{\text {nd }}$ ed. Vol. II the Proteo bacteria., Springer Verlage.

Bonartseva, G.A.; Myshkina, V.L. and Zagreba, E.D. (1994): Polyhydroxybutyrate content in cells of various Rhizobium species during growth with different carbon and nitrogen sources. Microbiol., 63(1): 45-48.

Bormann, E.J.; LeiBner, M.and Beer, B.(1998): Growth associated production of poly (hydroxybutyric acid) by zotobacterb-eijerinckii from organic nitrogen substrates. Appl. Microbiol. Biotechnol.,49: 84- 88.

Bowker, R.R. (1981): Manual of Methods for General Bacteriology. American Society for Microbiology. Washington, D.C

Burdman,S.; Jurkevitch, F.; Schwartshurd, B.; Hampal, M. and Okon, Y. (1998): Aggregation in Azospirillum brasilense : effects of chemical and physical factors and involvement of extracellular components. Microbial., 144:1989-1999.

Dahi, M.K.;D. Schmiedel and W. Hillen, (1995): Glucose and glucose -6phosophate interaction with xylose repressor proteins from Bacillus spp. May contribute to the regulation of xylose utilization. J. Bacteriol., 177: 5467-5472.

Das, Q.; Chowdhury, J.U. and Anwar, M.N. (2005): Isolation, purification and characterization of biodegradable polymer producing bacteria Pseudomonas pseudomallei. Int. J. Agri. Biol., 7(1): 114-117.

Du, G.; Chen, J.; Yu, J. and Lun, S. (2001): Continuous production of poly-3hydroxybutyrate by Ralstonia eutropha in a two stage culture system. J. Biotech., 88: 59-65.

Ghate, B.; Paandit, P.; Kulkarni, C.; Mungi, D.D. and T.S. Patel, (2011): PHB Production using novel agro-industrial sources from different Bacillus species. Internat. J. Pharma Bio Sci., 2(3): 242 249.

Holmes, P.A. (1985): Applications of PHBs: A microbially produced biodegradable thermoplastic. Phys. Technol., 16: 32-36.

Ishizaki, A. and Tanaka, K. (1991): Production of poly- $\beta$-hydroxybutytic acid from carbon dioxide by Alcaligenes eutrophus ATCC17697. J. Ferm. and Bioeg.,71(4): 254-257.

Khanna, S. and Srivastava, A.K. (2005b): Statistical media optimization studies for growth and PHB production by Ralstonia eutropha. Process Biochem., 40: 21732182.

Kuniko, M.; Nakamura, Y.and Doi, Y. (1988): New bacterial coployestras produced in Alcaligenes eutrophus from organic acids. Polymer Commun., 29: 174-176.

Lee, S.Y. (1996): Bacterial polyhydroxyalkanoates. Biotechnol. Bioeng., 49: 1-14.

Lee, S.Y. (1996): Plastic bacteria progress and prospects for polyhydroxyalkanoate production in bacteria. Trends. Biotechnol., 14: 431-438. 
Mahishi, L.H.; Tripathi, G.and SRawal,.K. (2003): Poly (3-hydroxybutyrate) (PHB) synthesis by recombinant Escherichia coli harboring Streptomyces aureofaciens Poly-3-hydroxybutyrate biosynthesis genes: Effect of various carbon and nitrogen sources. Microbiol. Res., 158:19-27.

Miller, G.L. (1959): Use of Dinitrosalicylic acid reagent for determination of reducing sugar. Anal. Chem., 31: 426428.

Morita, M.; Tanji, Y.; Mizoguchi, K.; Soejima, A.; Orito, Y.and Unno, $\mathrm{H}$. (2001): Antibacterial activity of Bacillus amyloliquefaciens phage endolysin without holing conjugation.J. Biosci. Bioeng., 91: 469-473.

Page, W.J. (1992b): Suitability of commercial beet molasses fractions as substrates for polyhydroxyalkanoate production by Azotobacter vinelandii UWD. Biotechnol. Lett., 14: 385-390.

Panigrahi, S and Badveli, U.(2013):Screening, Isolation and Quantification of PHBProducing Soil Bacteria. Int. J. of Eng. Sci. Invention.,(2) 9:01-06.

Philip, S.; T. Keshavarz and Roy, I. (2007): Polyhroxyalkanoates: biodegradable polymers with a range of application. $\mathrm{J}$. Chem. Technol. Biotechnol., 82: 233247.

Rehm, B.H. and Valla, S. (1997): Bacterial alginates: Biosynthesis and applications. Appl. Microbiol. Biotechnol., 48: 281288.

Santimano, M.C.; Nimali, N.; Prabhu, and S. Garg, (2009): PHA production using a low cost agro industrial waste by Bacillus sp. Strain COL1/A6. Res. J. Microbiol., 4(3): 89-96.

Spiekerman, P.; Rehm, B.H.; Kalscheuer, R.; Baumeister D.and Stenbuchel, A. (1999): A sensitive, viable-colony staining method using Nile red for direct screening of bacteria that accumulate polyhydroxylakanoic acids and other lipid storage compounds. Arch . Microbiol., 171: 73-80 .

Wang, Y. J.; Hua, F. L.; Tsang, Y. F.; Chan, S.Y.; Sin, S. N.; Chua, H. M; Yu, P. H. F. and Ren, N. Q. (2007): Synthesis of PHAs from waste water under various $C$ : $\mathrm{N}$ ratios. Bioresource Technol., 98:16901693.

Williamson, D.H. and Wilkinson, J.F. (1958): The isolation and estimation of the poly- $\beta$ hydroxybutyrate inclusions of Bacillus species. J. Gen. Microbiol., 19: 198-209.

Yu, H.; Yin, J.; Li, H.; Yang, S. and Shen, Z. (2000): Construction and selection of the novel recombinant Escherichia coli. Eur. J. Biosci. Bioeng., 89: 307-311.

Zakaria, M. R.; Ariffin, H.; Johar, N. A. M.; Aziz, S. A.; Nishida, H.; Shirai, Y.and Hassan M. A.(2010): Biosynthesis and characterization of poly (3hydroxybutyrate-co-3-hydroxybutyrate) copolymer from wild type Comamonas sp. EB172. Polym. Degrad. Stab., 95: 1382-1386.

Zhang, S.; Kolvek, S.; Lenz, R.W. and Goodwin, S.(2003): Mechanism of the polymerization reaction initiated and catalyzed by the polyhydroxybutyrate synthase of Ralsotonia eutropha. Biomacromol., 4: 504-509.

\section{How to cite this article:}

Jehan Mohamed El-Mohamedy Hawas, Tarek El-Said El-Banna, Elsayed Belal Abdelmonteleb Belal and Ahmed AhmedAbd El-Aziz. 2016. Production of Bioplastic from some selected Bacterial strains. Int.J.Curr.Microbiol.App.Sci. 5(1): 10-22. doi: 'inttp://dx.doi.org/10.20546/ijcmas.2016.5011.002 